\title{
PERAN GENDER DALAM PENGAMBILAN KEPUTUSAN RUMAH TANGGA NELAYAN DI KOTA SEMARANG UTARA, PROVINSI JAWA TENGAH
}

\author{
Achmad Azizi, Hikmah dan Sapto Adi Pranowo \\ Balai Besar Penelitian Sosial Ekonomi Kelautan dan Perikanan \\ JI. KS. Tubun Petamburan VI Jakarta 10260 \\ Telp. (021) 53650162, Fax. (021)53650159 \\ Diterima 21 Februari 2011 - Disetujui 4 Juni 2012
}

\begin{abstract}
ABSTRAK
Penelitian ini bertujuan menganalisis peran gender dalam pengambilan keputusan pada rumah tangga nelayan dan telah dilakukan pada tahun 2007. Riset ini menggunakan metoda survei dengan studi kasus di kota Semarang Utara. Metode pengumpulan data dilakukan dengan cara Focus Group Discussion (FGD) dan wawancara terstruktur dengan menggunakan kuesioner tertutup terhadap 30 orang responden. Metode analisis data yang digunakan adalah analisis statistik deskriptif. Hasil riset menunjukkan bahwa tidak ada pengaruh gender atau pengambilan keputusan dilakukan secara bersama-sama antara suami istri pada kegiatan domestik, kegiatan produktif berupa investasi serta sosial kemasyarakatan. Pengaruh gender, yaitu didominasi oleh laki-laki (suami), hanya ditemukan pada pengambilan keputusan terkait dengan pengelolaan usaha perikanan masih didominasi oleh laki-laki (suami).
\end{abstract}

Kata Kunci: gender, pengambilan keputusan, rumah tangga nelayan, Kota Semarang Utara

\section{Abstract : The Role of Gender in Household Decision-making at Fisherman in the City of North Semarang, Central Java Province a Case Study in the City of North Semarang. By: Achmad Azizi, Hikmah and Sapto Adi Pranowo.}

The study aims to analyze the role of gender in decision-making at the household fishermen have been done in 2007. This research used a survey method with a case study in the northern city of Semarang. The method of data collection is done by Focus Group Discussion (FGD) and structured interviews using questionnaires covered the 30 respondents. Data analysis method used is descriptive statistical analysis. The results showed that there was no effect of gender or decision made jointly between husband and wife in domestic activities, such as investment in productive activities and social. The influence of gender, which is dominated by men (husbands), was found only in decision making related to the management of fishing effort is still dominated by men (husbands).

Keywords: gender, decision making, fisher's households, City of North Semarang 


\section{PENDAHULUAN}

Kegiatan perikanan tangkap di Kota Semarang Utara sudah lama dilakukan oleh nelayan dan merupakan usaha yang turun temurun. Kota Semarang Utara merupakan sentra daerah perikanan tangkap di Jawa Tengah dan kegiatan usaha penangkapan ikan sudah dapat memberikan kontribusi terhadap pendapatan keluarga. Peranan istri nelayan dalam usaha perikanan tangkap cukup besar dalam menyiapkan kebutuhan melaut dan disamping itu banyak istri nelayan yang bekerja sebagai pengolahan untuk mencukupi kebutuhan keluarga. Hal ini menurut Seruan (2000) bahwa wanita nelayan mendominasi bekerja di bidang industri pengolahan hasil perikanan,pedagang ikan,dan persiapan operasional, sedangkan laki-laki bekerja dalam operasional penangkapan saja.

Gender dikonstruksikan masyarakat adalah prilaku-prilaku dan harapan-harapan yang dikaitkan kepada perempuan dan lakilaki (Laporan Penelitian Bank Dunia, 2002). Perwujudan gender pada suatu masyarakat tidak selalu sama, hal ini tergantung pada nilai, norma yang dianut, agama, kepercayaan dan yang lain-lain. Menurut Srini et al., 2000 peran gender merupakan suatu persoalan ketika nilai-nilai yang terkandung dalam ketentuan gender tersebut menghambat seseorang mempunyai akses dan kontrol terhadap sumber daya dan hasil-hasilnya.

Sebagai upaya peningkatan kesetaraan gender dan keadilan gender (laki-laki dan perempuan), Pemerintah Indonesia telah meratirifikasi sejumlah konvensi internasional yang berkaitan dengan hak perempuan, seperti CEDAW (Convention on the Elimination of All From Discrimination Against Women), serta menandatangani strategi kedepan untuk kemajuan perempuan (CIDA, Agritem dan LP3ES, 1999).

Persepsi adalah selektifitas ketika kita cenderung memperhatikan hanya bagian-bagian tertentu dari suatu obyek atau orang. Dengan kata lain, kita melakukan seleksi hanya pada karakteristik tertentu dari obyek persepsi dan mengabaikan yang lain. Dalam hal ini biasanya mempersiapkan apa yang kita inginkan atas dasar sikap, nilai dan keyakinan dalam diri kita, dan mengabaikan karakteristik yang tidak relevan atau yang belainan dengan nilai keyakinan tersebut (Djuarsa dan Turnomo. 1994).

Faktor-faktor internal juga mempengaruhi atensi sebagai salah satu aspek persepsi, tetapi yang mempengaruhi persepsi kita secara keseluruhan, terutama penafsiran atas suatu rangsangan. Agama, ideologi, tingkat intelektualitas, tingkat ekonomi, pekerjaan dan cita rasa sebagai faktor-faktor internal yang dengan jelas mempengaruhi persepsi seseorang terhadap suatu realitas (Mulyana, 2000).

Selama ini, peran dan kontribusi perempuan (istri) nelayan di Kota Semarang Utara terhadap ekonomi cukup memegang peranan penting, namun peran tersebut belum didukung sepenuhnya oleh kebijakan pemerintah yang memihak kepada wanita. Menurut Fakih (2003) dari studi yang dilakukan dengan menggunakan analisis gender ini, tenyata banyak menemukan manifestasi ketidakadilan seperti berikut: Pertama, terjadi marjinalisasi perempuan disebabkan oleh ketidakadilan gender, namun yang dipersoalkan dalam analisis gender adalah marjinalisasi (pemiskinan ekonomi) terhadap kaum perempuan. Meskipun tidak semua marjinalisasi perempuan yang disebabkan oleh perbedaan gender. Kedua, terjadinya subordinasi pada salah satu jenis kelamin, umumnya kepada kaum perempuan. Dalam rumah tangga, masyarakat maupun negara, banyak kebijakan dilaut tanpa "menganggap penting" kaum perempuan. Ketiga, adalah pelabelan negatif (stereotype) terhadap jenis kelamin tertentu dan akibatnya terjadi diskriminasi serta berbagai ketidakadilan lainnya. Dalam masyarakat, banyak sekali stereotype yang dilekatkan kepada kaum perempuan yang berakibat membatasi, menyulitkan, memiskinkan dan merugikan kaum perempuan. Keempat, kekerasan (violence) terhadap jenis kelamin tertentu, umumnya perempuan, 
karena perbedaan gender. Kekerasan ini mencakup kekerasan fisik seperti pemerkosaan dan pemukulan sampai kekerasan-kekerasan dalam bentuk yang lebih halus seperti pelecehan dan penciptaan ketergantungan. Kelima, karena peran gender perempuan menanggung beban kerja domestik lebih banyak dan lebih lama (burden) dengan kata lain peran perempuan mengelola, menjaga dan memelihara kerapihan tersebut, sehingga mengakibatkan tumbuhnya tradisi dan keyakinan masyarakat bahwa mereka harus bertanggung jawab atas terlaksananya keseluruhan pekerjaan domestik.

Sosialisasi peran gender tersebut menimbulkan rasa bersalah dalam diri perempuan jika tidak menjalankan tugastugas domestik tersebut. Rahardjo (1995) mengatakan bahwa perempuan secara ekonomi dapat menambah mendapatan keluarga, sehingga pendapatan istri dapat membantu mengentaskan kemiskinan, sedangkan Sirait dalam Kusnadi (2001) mengemukakan fakta bahwa istri-istri nelayan yang bekerja sebagai pedagang dan pengolah mempunyai akses dan kontrol yang penuh terhadap sumber daya keluarga.

Tulisan ini bertujuan untuk memberikan gambaran tentang profil rumah tangga nelayan, peran gender dalam pengambilan keputusan pada rumah tangga nelayan dan menopang upaya peningkatan pendapatan rumah tangga serta diharapkan dapat dijadikan langkah awal untuk melakukan strategi kebijakan yang mengarah kepada kebijakan pengembangan dan pemberdayaan perempuan.

\section{METODOLOGI}

\section{Kerangka Pemikiran}

Gender dikonstruksikan masyarakat adalah perilaku-perilaku dan harapanharapan yang dikaitkan kepada perempuan dan laki-laki dan menjadi persoalan ketika nilai-nilai yang tergantung dalam ketentuan gender dapat menghambat seseorang dalam akses dan kontrol terhadap sumberdaya perikanan. Pada prinsipnya ekonomi keluarga didominasi oleh kaum laki-laki dan merupakan terjemahan bahwa kekuasaan laki laki mendorong kaum perempuan menjadi orang kedua yang kurang diperhitungkan dibandingkan dengan kaum laki-laki.

Kaum laki-laki mempunyai anggapan bahwa laki-laki adalah orang yang merupakan mencari nafkah utama untuk kebutuhan ekonomi keluarga atau laki-laki sebagai pekerja produktif yang sangat dominan, namun kadang-kadang pada kenyataannya tidak demikian, banyak kaum perempuan yang menjadi penanggung ekonomi keluarga. Akan tetapi sebagian besar kaum lakilaki beranggapan bahwa dalam keluarga merupakan peranan penghasil kebutuhan rumah tangga dan penentu pengambilan keputusan. Menurut Kusnadi (2001) masyarakat nelayan terdapat pola pembagian kerja secara seksual yang sangat kuat pengaruhnya terhadap kultural masyarakat yaitu " laut adalah merupakan milik atau wilayah laki-laki, sedangkan perempuan daratan merupakan wilayahnya, namun dengan alasan ekonomi penghasilan suami tidak mencukupi kebutuhan keluarga, maka istri yang harus bekerja untuk menambah penghasilan keluarga.

\section{Metode penelitian}

Penelitian ini menggunakan metoda survei dan metode bersifat kualitatif digunakan dalam penelitian ini dengan mengambil bentuk studi kasus dan membatasi pada suatu komunitas rumah tangga nelayan di Kota Semarang Utara sebagai sasaran studi. Menurut Yin (2002) studi kasus merupakan metode yang dianggap tepat untuk menjawab pertanyaan "bagaimana, mengapa" serta tepat bagi penelitian yang hanya memiliki peluang kecil sekali atau tidak mempunyai peluang sama sekali untuk melakukan kontrol terhadap peristiwa tersebut. 
Peran wanita dalam aktivitas produktif dirasakan masih terbatas, hal ini dikarenakan perempuan tugasnya hanya mengurus rumah tangga, seperti mengurus suami, anak dan memasak, sedangkan yang sifatnya menghasilkan pendapatan masih merupakan wewenang suami, sehingga banyak para wanita yang hanya tinggal di rumah saja.

Batasan unit analisisnya adalah rumah tangga nelayan yang meliputi sejumlah orang atau kasus (peristiwa lokal), sehingga membatasi peluang untuk generalisasi, namun memungkinkan pemahaman yang mendalam tentang peristiwa atau gejala sosial tertentu. Tujuan penelitian kualitatif adalah pertama untuk mengetahui apa atau bagaimana peristiwa atau gejala sosial yang sedang terjadi (eksploratif); kedua, untuk menerangkan mengapa sesuatu peristiwa atau gejala sosial terjadi (Sitorus,1998).

\section{Lokasi dan Waktu Penelitian}

Kota Semarang Utara merupakan daerah pesisir pantai utara Jawa dan mempunyai potensi yang cukup besar terhadap aktivitas perikanan tangkap, disamping itu sebagai daerah sentra aktivitas nelayan baik nelayan tangkap maupun pengolahan. Pemilihan lokasi didasari oleh aktivitas masyarakat sebagai nelayan, kegiatan pengolahan ikan dan peranan perempuan dalam aktivitas kegiatan perikanan cukup besar terutama dalam bidang usaha pengolahan ikan. Waktu penelitian peran gender dalam pengambilan keputusan rumah tangga nelayan di Kota Semarang Utara dilakukan pada bulan Juli 2007.

\section{Pengumpulan Data}

Dalam penelitian ini data yang dikumpulkan berupa data primer dan data sekunder. Data primer dikumpulkan dari hasil wawancara dengan responden nelayan seperti pemilik kapal, juragan laut dan anak buah kapal, Jumlah responden adalah 30 orang yang terdiri dari 18 responden pemilik kapal dan anak buah kapal (ABK) sebanyak 12 orang. Pengumpulan data primer dilakukan dengan dua cara:

1. Melakukan diskusi kelompok (Focus group discussion). Diskusi ini dilakukan d tahap yaitu: pertama, diskusi yang diikuti oleh laki-laki yang bertujuan untuk mendapatkan masukan tentang berbagai hal seperti tanggapan mereka tentang nilai gender dan peran gender dalam masyarakat. Kedua, diskusi yang diikuti oleh perempuan, dimaksudkan untuk menggali lebih dalam tentang makna kerja bagi mereka, demikian juga tentang nilai dan peranan gender dalam rumah tangga dan masyarakat.

2. Melakukan wawancara terstruktur kepada 30 orang responden yang dipilih secara acak sederhana (random sampling). Pengumpulan data primer dilakukan melalui wawancara dengan responden pemilik kapal (juragan darat) dan juragan laut/ABK dengan bantuan kuesioner terpola yang sudah disiapkan terlebih dahulu sesuai dengan tujuan yang ingin dicapai dalam penelitian ini. Disamping itu dilakukan juga observasi lapang guna mengetahui kondisi masyarakat nelayan setempat terutama terkait dengan perumahan dan lingkungannya serta pola pemukiman.

Data sekunder yang dikumpulkan mencakup informasi yang berkaitan dengan gambaran fisik daerah penelitian serta keragaan sosial eknomi daerah penelitian diperoleh dari dokumen atau arsip tertulis, laporan hasil penelitian dan publikasi lainnya dari Dinas Kelautan dan Perikanan Kota Semarang maupun lembagan penelitian lainnya.

\section{Analisis Data}

Data kuantitatif hasil wawancara terstruktur dengan responden dilakukan dengan cara tabulasi silang, dan persentase, serta disajikan dalam bentuk tabel. Analisis data secara kualitatif dilakukan melalui tiga jalur analisis: reduksi data, penyajian data dan penarikan kesimpulan (Miles dan 
Hubeman, 1992). Data kualitatif digunakan untuk menambah memperkaya pemahaman tentang isu-isu pokok penelitian. Dengan demikian akan diperoleh gambaran yang utuh terkait dengan karakteristik sosial ekonomi dan budaya maasyarakat nelayan, pola pembagian kerja dan curahan waktu serta kontribusi geder terhadap pendapatan rumah tangga nelayan. Sebagai studi kasus, hasil penelitian ini hanya berkisar pada komunitas yang diteliti.

\section{HASIL DAN PEMBAHASAN}

\section{Profil Rumah Tangga Nelayan}

\section{Status Keluarga Nelayan Terkait Usaha Penangkapan}

Sesuai dengan melimpahnya dukungan sumber daya alam di sektor perikanan dan kelautan di daerah Kota Semarang Utara sebagian besar masyarakat pekerjaan utama suami dalam keluarga adalah sebagai nelayan dan pekerjaan ini sudah turun temurun dari orang tuanya. Sebaran status keluarga nelayan dapat dilihat pada Tabel 1.
Tabel 1 menunjukkan kategori responden suami lebih besar berstatus sebagai nelayan pemilik kapal yaitu dengan persentase 60 persen atau 18 orang dibandingkan bukan sebagai pemilik kapal yaitu 40 persen (12 orang). Namun sedikit yang berstatus sebagai juragan laut/nahkoda/juru mudi yaitu sebesar $13,33 \%$ (4 orang) dan berstatus sebagai ABK yaitu $10 \%$ (3 orang). Begitu pula dengan responden istri, hanya sedikit istri yang bekerja di sektor perikanan dengan kategori sebagai bakul ikan sebesar 3,33\% (1 orang) dan sebagai pengolah ikan sebesar $30 \%$ (9 orang). Hal ini terjadi karena banyak istri yang tidak bekerja dan hanya melakukan pekerjaan rumah saja maupun istri yang bekerja di luar bidang perikanan seperti berdagang, menjadi buruh atau menjadi TKW.

Sementara itu tidak ditemukan istri yang bekerja sebagai nelayan. Jenis pekerjaan ini tidak dipilih oleh para istri karena berdasarkan pada waktu pelaksanaannya yang bersamaan dengan tugas utama istri mengurus rumah tangga sehingga tidak dapat melakukan pekerjaan sebagai nelayan.

Tabel 1. Status Responden dalam Kepemilikan Armada Penangkapan di Lokasi Riset. Table 1. Ownership Status of Respondents in the Research Fleet of Fishing Location.

\begin{tabular}{|c|c|c|c|c|c|}
\hline \multirow[b]{2}{*}{ No } & \multirow[b]{2}{*}{$\begin{array}{l}\text { Status Responden/ } \\
\text { Status of Respondents }\end{array}$} & \multicolumn{2}{|c|}{ Suami/ Husband } & \multicolumn{2}{|c|}{ Istri/ Wife } \\
\hline & & $\begin{array}{l}\text { Jumlah } \\
\text { Responden/ } \\
\text { Number of } \\
\text { Respondent }\end{array}$ & (\%) & $\begin{array}{l}\text { Jumlah } \\
\text { Responden/ } \\
\text { Number of } \\
\text { Respondent }\end{array}$ & (\%) \\
\hline 1 & $\begin{array}{l}\text { Nelayan pemilik kapal } \\
\text { (juragan darat)/ } \\
\text { Boat owner }\end{array}$ & 18 & 60.00 & 0 & 0 \\
\hline 2 & $\begin{array}{l}\text { Juragan Laut, Nakhoda, } \\
\text { Juru Mudi dan ABK/ Sea } \\
\text { squire, captain, helmsman } \\
\text { and crew }\end{array}$ & 12 & 40.00 & 0 & 0 \\
\hline 3 & Bakul ikan/ Retailer & 0 & 0 & 4 & 13.33 \\
\hline 4 & $\begin{array}{l}\text { Pedagang ikan olahan/ } \\
\text { Fish seller Processing }\end{array}$ & 0 & 0 & 5 & 14.67 \\
\hline 5 & $\begin{array}{l}\text { Pengolah ikan/ } \\
\text { Fish Processing }\end{array}$ & 0 & 0 & 14 & 46.67 \\
\hline
\end{tabular}

Sumber: Data Primer diolah, 2007/Source: Primary data processed, 2007 


\section{Tingkat Pendidikan}

Tingkat pendidikan merupakan hal yang sangat penting dalam pengelolaan suatu usaha, baik pendidikan formal maupun non formal. Pendidikan formal merupakan modal yang sangat berharga untuk mendapatkan kehidupan ekonomi yang layak. Pendidikan juga sangat berpengaruh terhadap pola kehidupan pada setiap individu, baik cara berfikir, cara pengambilan keputusan dan cara bersikap. Sebaran tingkat pendidikan formal yang dicapai oleh responden di Semarang Utara dapat disajikan pada Tabel 2.

Tabel 2 menunjukkan bahwa tingkat pendidikan formal responden cukup bervariasi mulai tidak tamat sekolah dasar sampai tamat sekolah tingkat pertama. Rata-rata sebaran tingkat pendidikan keluarga nelayan masih didominasi tingkat pendidikan rendah yakni tamat sekolah dasar. Rendahnya tingkat pendidikan responden diakibatkan oleh tingkat pendapatan orangtuanya yang sangat kecil, sehingga responden harus membantu orang tuanya untuk mengambil ikan dilaut. Disisi lain, masih adanya sebagian orang tua yang memiliki persepsi bahwa anak perempuan tidak diperlu berpendidikan tinggi dengan alasan bahwa wanita lebih penting mengerjakan kegiatan domestik seperti mengurus anak, mengurus rumah dan suami.

\section{Kisaran Sebaran Tingkat Pendapatan}

Tingkat pendapatan responden merupakan faktor yang sangat penting dalam kehidupan dan kesejahteraan keluarga, pendapatan seseorang akan berpengaruh terhadap tingkat kesejahteraan keluarganya. Makin tinggi tingkat pendapatannya diharapkan akan makin tinggi sejahtera tingkat kehidupannya. Penentuan kriteria tingkat pendapatan berdasarkan 3 katagori yaitu rendah, sedang dan tinggi. Hasil dari analisa data tingkat pendapatan nelayan dan istri nelayan dapat disajikan pada Tabel 3.

Pada Tabel 3 menunjukkan bahwa tingkat pendapatan nelayan di lokasi riset pada umumnya rendah, dimana $80 \%$ (24 responden) termasuk dalam katagori tingkat pendapatannya sangat rendah, 4 orang (13\%) termasuk dalam kategori pendapatan yang sedang, sedangkan yang masuk dalam kategori tingkat pendapatannya yang tinggi hanya $7 \%$, penghasilan

Tabel 2. Kisaran Sebaran Tingkat Pendidikan Formal Responden (Suami-Istri di Kota Semarang Utara (N:30).

Table 2. Range Distribution Formal Education Level of Respondents (Husband and Wife in North Semarang City ( $N$ : 30).

\begin{tabular}{|c|c|c|c|c|c|}
\hline \multirow[b]{2}{*}{ No } & \multirow[b]{2}{*}{ Kategori/ Category } & \multicolumn{2}{|c|}{$\begin{array}{l}\text { Responden Suami/ } \\
\text { Husband Respondent }\end{array}$} & \multicolumn{2}{|c|}{$\begin{array}{l}\text { Responden Istri/ } \\
\text { Wife Responden }\end{array}$} \\
\hline & & $\begin{array}{l}\text { Jumlah Orang/ } \\
\text { Number of } \\
\text { Respondent }\end{array}$ & (\%) & $\begin{array}{l}\text { Jumlah Orang/ } \\
\text { Number of } \\
\text { Respondent }\end{array}$ & (\%) \\
\hline 1 & Tidak sekolah/ Drop out & 0 & 0 & 0 & 0 \\
\hline 2 & Tidak tamat SD/ Drop out & 1 & 3.3 & 11 & 36.67 \\
\hline 3 & Tamat SD/ Primary school & 16 & 56.7 & 11 & 36.67 \\
\hline 4 & $\begin{array}{l}\text { Tidak tamat SMP/ } \\
\text { No graduate school }\end{array}$ & 6 & 16.7 & 7 & 23.33 \\
\hline 5 & $\begin{array}{l}\text { Tamat SMP/ Graduated } \\
\text { from junior high }\end{array}$ & 7 & 23.3 & 1 & 3.33 \\
\hline & Total & 30 & 100 & 30 & 100 \\
\hline
\end{tabular}

Sumber: Data Primer diolah, 2007/Source: Primary data processed, 2007 
Tabel 3. Sebaran Tingkat Pendapatan Nelayan Responden Per Bulan di Kota Semarang Utara, 2007.

Table 3. Fisher's Income Level Distribution of Respondents per Month in the City of North Semarang, 2007.

\begin{tabular}{|c|c|c|c|c|c|}
\hline \multirow{2}{*}{$\begin{array}{c}\text { Pendapatan } \\
\text { Suami (Rp/bulan)/ } \\
\text { Husband Income } \\
\mathrm{N}=30\end{array}$} & \multirow{2}{*}{$\begin{array}{c}\text { Jumlah } \\
\text { Responden/ } \\
\text { Number of } \\
\text { Respondent } \\
\text { (\%)/ }\end{array}$} & \multicolumn{4}{|c|}{$\begin{array}{l}\text { Pendapatan Istri (Rp/bulan)/ } \\
\text { Wife's Income } \mathrm{N}=30\end{array}$} \\
\hline & & $\begin{array}{l}\text { Rendah/ } \\
\text { Low }\end{array}$ & $\begin{array}{l}\text { Sedang/ } \\
\text { Midle }\end{array}$ & $\begin{array}{l}\text { Tinggi/ } \\
\text { High }\end{array}$ & $\begin{array}{l}\text { Jumlah/ } \\
\text { Total }\end{array}$ \\
\hline Rendah/ Low & $24(80)$ & $24(80)$ & $0(0.00)$ & $0(0.00)$ & $24(80)$ \\
\hline Sedang/ Midle & $4(13)$ & $6(20)$ & $0(0.00)$ & $0(0.00)$ & $6(20)$ \\
\hline Tinggi/ High & $2(7)$ & 0 & $0(0.00)$ & $0(0.00)$ & 0 \\
\hline Jumlah/ Total & $30(100.00)$ & $30(60.00)$ & 0 & 0 & $30(100.00)$ \\
\hline
\end{tabular}

Sumber: Data Primer diolah, 2007/Source: Primary data processed, 2007

Keterangan/Remarks:

Pendapatan rendah/Low income $=<$ Rp.500,000

Pendapatan Sedang/Midle income $=$ Rp.500.000-1.000.000

Pendapatan Tinggi/High income $=>$ Rp. 1000.000,-

responden ini adalah dalam kurun waktu satu bulan.Sedangkan pendapatan istri sebagai penunjang penghasilan suami termasuk dalam kategori rendah yaitu $80 \%$ dan yang termasuk kategori sedang adalah 20\%, kegiatan istri nelayan adalah sebagai buruh pengolahan ikan, seperti pembuatan pindang dan ikan asin. Pendapatan istri nelayan kalau dikaitkan dengan upah minimum regional pada umumnya masih di bawah upah minimum regional Kota Semarang

\section{Stratifikasi Sosial}

Pada komunitas masyarakat biasanya terdapat figur-figur anggota masyarakat yang dapat menjadi panutan bagi anggota masyarakat lainnya. kondisi tersebut membawa mereka pada kedudukan atau status sosial yang disebut sebagai tokoh masyarakat. Hal ini terjadi karena mereka dianggap memiliki otoritas dan pengaruh yang diakui oleh masyarakatnya baik dalam bentuk yang sudah terlembagakansecara adat (institutionalized) maupun yang belum terlembagakan. Sumber-sumber pengaruh dapat berasal dari penguasaan modal, kepemilikan alat produksi maupun karena proses pewarisan sistem nilai atau tradisi tertentu.
Menurut Soekanto (1990), bahwa penggolongan anggota masyarakat dalam suatu kedudukan dapat terjadi karena ukuran kekayaan, ukuran kekuasaan, ukuran kehormatan dan ukuran ilmu pengetahuan, yang mana kedudukan ini dapat diperoleh dengan dua cara yaitu karena kelahiran atau keturunan dan karena usahausaha yang dilakukan dengan sengaja. Menurut Sorokin (1962) dalam Satria (2002) menjelaskan bahwa stratifikasi dalam masyarakat yang mengandung pola kepemimpinan atau ketokohan masyarakat ini dapat terbentuk berdasarkan faktor ekonomi, faktor pekerjaan atau faktor politik.

Rata-rata responden status sosial dalam keluarga nelayan di Kota Semarang adalah sebagai anggota masyarakat biasa. Hal ini disebabkan tingkat pendidikan yang masih rendah dan kurangnya hubungan sosial masyarakat nelayan karena kesibukannya setiap hari harus pergi menangkap ikan ke laut.

Dalam status sosial di masyarakat nelayan Kota Semarang masih terdapat ketidaksetaraan antara laki-laki dan perempuan, baik status sosial sebagai tokoh masyarakat, pemuka agama maupun pemimpin adat. Hal ini disebabkan karena 
di dalam masyarakat wanita masih tabu untuk menjabat sebagai pimpinan, walaupun wanita memiliki kemampuan untuk memangku jabatan tersebut.

Kota Semarang, khususnya Semarang Utara adalah kawasan pemukiman dan perumahan dengan intensitas tinggi, karena berada dekat dengan kawasan industri, perdagangan, pergudangan, dan pelabuhan laut. Konsekuensi logis, apabila kawasan ini diminati oleh para nelayan dan buruh yang tempat bekerjanya berdekatan dengan tempat tinggalnya.

Hasil survei lapangan menunjukkan bahwa kondisi sosial masyarakat nelayan Kota Semarang Utara jika dilihat dari sisi ekonomi, dapat dibedakan atas dua golongan yaitu golongan atas dan golongan bawah. Perbedaan ini dapat dicirikan secara fisik, yaitu kebiasaan pola hidup cenderung sama pada golongan tertentu. Golongan atas biasanya adalah nelayan pemilik, tengkulak dan pemilik toko yang bergerak dibidang perikanan, seperti pengadaan alat tangkap, solar dan sembako, sedangkan untuk kelas golongan bawah adalah nelayan pekerja, tukang ojek, tukang becak dan pemilik warung minuman.
Dalam kegiatan penangkapan, masih belum ada pembagian kerja yang berstruktur. Tidak ada spesialisasi pekerjaan masingmasing pekerja dalam pengoperasian kapal antara pemilik kapal, jurangan dan anak buah kapal (ABK). Pemilik kapal ikut juga dalam penangkapan ikan dan bertanggung jawab yang sama dengan nelayan ABK lainnya. Pemilik kapal juga bisa sebagai juru mudi atau pun dapat sebagai penebar jaring dan pengangkat jaring.

\section{Profil Aktivitas dalam Rumah Tangga Nelayan}

Profil kegiatan responden yang dilakukan sehari-hari mencakup kegiatan produktif, kegiatan domestik, waktu luang dan kebutuhan dasar keluarga dan aktivitas sosial yang akan dikaji dalam penelitian ini. Curahan waktu untuk kegiatan produktif yang dilakukan oleh para suami dalam satu hari adalah 9,42 jam, sedangkan istri melakukan kegiatan produktif mencapai 2,6 jam, sedangkan untuk kegiatan domestik curahan waktu yang digunakan oleh suami mencapai 3,98 jam dan curahan waktu yang digunakan oleh istri mencapai 8,5 jam. Dalam curahan waktu produktif pekerjaannya dibebankan kepada laki-laki dan tugas

Tabel 4. Sebaran Status Sosial Masyarakat Nelayan di Kota Semarang Utara.

Table 4. Distribution of Social Status Community Fisherman in the City of North Semarang.

\begin{tabular}{|c|c|c|c|c|c|}
\hline \multirow[b]{2}{*}{ No } & \multirow[b]{2}{*}{ Status Sosial/ Status Social } & \multicolumn{2}{|c|}{ Suami/ Husband } & \multicolumn{2}{|c|}{ Isteri/ Wife } \\
\hline & & $\begin{array}{l}\text { Jumlah } \\
\text { Responden/ } \\
\text { Number of } \\
\text { Respondent } \\
\end{array}$ & (\%) & $\begin{array}{l}\text { Jumlah } \\
\text { Responden/ } \\
\text { Number of } \\
\text { Respondent } \\
\end{array}$ & (\%) \\
\hline \multirow[t]{2}{*}{1} & $\begin{array}{l}\text { Pemuka agama/ Religious } \\
\text { leaders }\end{array}$ & 0 & 0 & 0 & 0 \\
\hline & $\begin{array}{l}\text { Pemimpin adat/Indigenous } \\
\text { leader }\end{array}$ & 1 & 3.33 & 0 & 0 \\
\hline 3 & $\begin{array}{l}\text { Tokoh masyarakat/ pemuka } \\
\text { pendapat/ Community } \\
\text { leaders/opinion leaders }\end{array}$ & 1 & 3.33 & 0 & 0 \\
\hline \multirow[t]{2}{*}{4} & $\begin{array}{l}\text { Anggota masyarakat biasa/ } \\
\text { Ordinary community } \\
\text { members }\end{array}$ & 28 & 94.34 & 30 & 100 \\
\hline & Jumlah/ Total & 30 & 100 & 30 & 100 \\
\hline
\end{tabular}

Sumber: Data Primer diolah, 2007/Source: Primary data processed, 2007 
perempuan/istri hanya melakukan pekerjaan yang banyak sifatnya domestik, seperti mengurus rumah tangga, mengurus anak, memasak dan mengurus suami.

Curahan waktu untuk kegiatan waktu luang dan kebutuhan dasar keluarga di lokasi riset adalah untuk curahan waktu yang digunakan suami 3,2 jam dan curahan waktu yang digunakan istri dalam satu hari mencapai 6,5 jam. Kegiatan aktivitas sosial untuk curahan waktu tersebut para suami menggunakan waktunya adalah 5,4 jam perminggu dan untuk istri nelayan curahan waktu yang digunakan adalah 2,9 jam perminggu. Curahan waktu kegiatan produktif, domestik, waktu luang dan kebutuhan dasar keluarga dan aktivitas sosial rumah tangga nelayan dapat dilihat pada Tabel 5.

Peran Gender dalam Pengambilan Keputusan dalam Rumah Tangga

\section{Pengambilan Keputusan dalam Kegiatan Domestik}

Pengambilan keputusan pada kegiatan domestik pada rumah tangga nelayan yang dilakukan oleh suami, istri dan suami dan istri seperti pendidikan untuk anak, kesehatan, tabungan, pengadaan alat rumah tangga, dan reproduksi lebih banyak dilakukan secara bersama, artinya pengambilan keputusan tidak didominasi oleh salah satu pihak (suami saja atau istri saja). Namun pada kegiatan tertentu seperti keputusan memilih menu masakan lebih dominan diputuskan oleh istri. Hal ini berarti tidak ada kesenjangan gender dalam pengambilan keputusan pada aktivitas domestik (Tabel 6).

\section{Pengambilan Keputusan dalam Kegiatan Publik}

Aktivitas produktif merupakan modal yang sangat penting dalam usaha kegiatan perikanan tangkap, dimana aktifitas produktif meliputi investasi/modal usaha perikanan, pengelolaan usaha perikanan, pengelolaan usaha pengolahan, pengelolaan usaha pengolahan, dan sosial kemasyarakatan. Dalam pengambilan keputusan dalam kepemilikan aktifitas produktif cukup bervariasi yaitu ada secara bersama, secara sendiri oleh pihak istri dan pengambilan keputusan langsung oleh suami.

Tabel 5. Curahan Waktu untuk Profil Kegiatan Produktif, Domestik, Waktu Luang dan Kebutuhan Dasar Keluarga dan Aktivitas Sosial di Kota Semarang Utara.

Table 5. Outpouring of Time to Profile Productive Activities, Domestic, Leisure Time and Basic Family Needs and Social Activities in the City of North Semarang.

\begin{tabular}{clcc} 
& Pofil Kegiatan/ Activity Profile & \multicolumn{2}{c}{ Curahan Waktu/ Time Expended (n=30) } \\
\cline { 3 - 4 } & $\begin{array}{c}\text { Suami (Jam/hari)/ } \\
\text { Husband }\end{array}$ & $\begin{array}{c}\text { Istri (Jam/hari)/ } \\
\text { Wife }\end{array}$ \\
\hline 1 & $\begin{array}{l}\text { Kegiatan produktif/ } \\
\text { Productive activities(Jam/hari) }\end{array}$ & 9.42 & 2.60 \\
\hline $\begin{array}{l}\text { Kegiatan domestik/ } \\
\text { Domestic activities(Jam/hari) }\end{array}$ & 3.98 & 8.50 \\
\hline $\begin{array}{l}\text { Waktu luang dan kebutuhan dasar } \\
\text { keluarga/ Leisure and the family basic } \\
\text { needs(Jam/hari) }\end{array}$ & 3.20 & 6.50 \\
\hline $\begin{array}{l}\text { Aktivitas sosial/ } \\
\text { Activities social work (Jam/minggu) }\end{array}$ & 5.40 & 2.90 \\
\hline
\end{tabular}

Sumber: Data primer diolah, 2007/Source: Primary data processed, 2007 
Tabel 6. Pengambilan Keputusan dalam Kegiatan Domestik Nelayan di Kota Semarang Utara. Table 6. Decision Making in Fishers Domestic Activity in the City of North Semarang.

\begin{tabular}{|c|c|c|c|c|}
\hline \multirow[b]{2}{*}{ No } & \multirow[b]{2}{*}{ Aktifitas Domestik/ Domestic Activity } & \multicolumn{3}{|c|}{$\mathrm{N}=30(\%)$} \\
\hline & & $\begin{array}{l}\text { Dominasi } \\
\text { Istri/ Wife } \\
\text { Domination }\end{array}$ & $\begin{array}{c}\text { Suami } \\
\text { + Istri/ } \\
\text { Husband + } \\
\text { Wife }\end{array}$ & $\begin{array}{l}\text { Dominasi } \\
\text { Suami/ } \\
\text { Domination } \\
\text { Husband }\end{array}$ \\
\hline \multirow[t]{3}{*}{1} & Penyediaan makanan/ Provision of food & & & \\
\hline & - Perencanaan menu/ Planning the menu & $29(96.67)$ & $1(3.33)$ & $0(0.00)$ \\
\hline & $\begin{array}{l}\text { - Cara mengolah dan penyajiannya/ How to } \\
\text { treat and presentation }\end{array}$ & $28(93.33)$ & $1(3.33)$ & $1(3.33)$ \\
\hline \multirow[t]{3}{*}{2} & Pendidikan anak/ Child education & & & \\
\hline & $\begin{array}{l}\text { - Memilih jenis sekolah/ Select type of } \\
\text { school }\end{array}$ & $3(10.00)$ & $24(80.00)$ & $3(10.00)$ \\
\hline & - Tingkat pendidikan/ Education level & $5(16.67)$ & $23(76.67)$ & $2(6.67)$ \\
\hline \multirow[t]{3}{*}{3} & $\begin{array}{l}\text { Kesehatan anggota keluarga/ Health family } \\
\text { members }\end{array}$ & & & \\
\hline & $\begin{array}{l}\text { - Memilih metode pengobatan/Selecting } \\
\text { treatment methods }\end{array}$ & $20(66.67)$ & $8(26.67)$ & $2(6.67)$ \\
\hline & $\begin{array}{l}\text { - Memilih tempat pengobatan/Select venue } \\
\text { treatment }\end{array}$ & $20(66.67)$ & $8(26.67)$ & $2(6.67)$ \\
\hline \multirow[t]{4}{*}{4} & Tabungan/ savings & & & \\
\hline & $\begin{array}{l}\text { - Keputusan untuk menabung/Decision to } \\
\text { save }\end{array}$ & $2(6.67)$ & $24(80.00)$ & $4(13.33)$ \\
\hline & $\begin{array}{l}\text { - Cara dan tempat menabung/ Ways and } \\
\text { saving place }\end{array}$ & $2(6.67)$ & $25(83.33)$ & $3(10.00)$ \\
\hline & - Perencanaan Penggunaan/ Use planning & $2(6.67)$ & $25(83.33)$ & $3(10.00)$ \\
\hline \multirow[t]{5}{*}{5} & $\begin{array}{l}\text { Pengadaan peralatan rumah tangga/ } \\
\text { Procurement household }\end{array}$ & & & \\
\hline & $\begin{array}{l}\text { - Pengadaan perlengkapan utama/Major } \\
\text { equipment procurement }\end{array}$ & $8(26.67)$ & $20(66.67)$ & $2(6.67)$ \\
\hline & $\begin{array}{l}\text { - Pengadaan peralatan hiburan/- } \\
\text { Procurement of equipment entertainment }\end{array}$ & $1(3.33)$ & $23(76.67)$ & $6(20.00)$ \\
\hline & $\begin{array}{l}\text { - Perbaikan bangunan rumah/Improved } \\
\text { building houses }\end{array}$ & $1(3.33)$ & $24(80.00)$ & $5(16.67)$ \\
\hline & $\begin{array}{l}\text { - Pengajuan kredit kendaraan/Application } \\
\text { for auto loans }\end{array}$ & $2(6.67)$ & $23(76.67)$ & $5(16.67)$ \\
\hline \multirow[t]{4}{*}{6} & Reproduksi/ Reproduction & & & \\
\hline & $\begin{array}{l}\text { - Penetapan jumlah anak/ Determination of } \\
\text { number of children }\end{array}$ & $2(6.67)$ & $23(76.67)$ & $5(16.67)$ \\
\hline & $\begin{array}{l}\text { - Pemilihan kontrasepsi/ Selection of } \\
\text { contraception }\end{array}$ & $16(53.33)$ & $13(43.33)$ & $1(3.33)$ \\
\hline & $\begin{array}{l}\text { - Penetapan jarak kelahiran/ Determination } \\
\text { of distance birth }\end{array}$ & $12(40.00)$ & $16(53.33)$ & $2(6.67)$ \\
\hline
\end{tabular}

Sumber: Hasil analisa data Primer 2007/Source: Primary data analysis, 2007 
Pada kegiatan publik, khususnya pada kegiatan produktif pengelolaan usaha perikanan baik dalam memilih jenis alat tangkap, perbaikan/ ganti alat tangkap, penetapan waktu penangkapan, penetapan harga, pemilihan sistem pemasaran dan pemilihan sistem pembayaran peranan suami sangat dominan sekali dalam pengambilan keputusan. Pada umumnya istri nelayan tidak banyak dilibatkan dalam pengambilan keputusan.Hal ini memperlihatkan bahwa dalam kegiatan produktif peran istri masih rendah. Dengan demikian ada indikasi kesenjangan gender dalam pengambilan keputusan pada kegiatan produktif.

Pada kegiatan sosial, ada kecenderungan pemisahan kelembagaan untuk perempuan dan laki-laki. Lembaga formal sosial seperti kegiatan PKK dan posyandu merupakan wadah bagi perempuan, sedangkan kegiatan kelompok nelayan seperti pelatihan, temu lapang merupakan wadah bagi laki-laki, sedangkan lemaga non formal seperti arisan dan pengajian merupakan wadah perempuan. Di Kecamatan Semarang Utara, istri istri nelayan mendapatkan bimbingan atau pelatihan tentang pengolahan ikan yaitu pengolahan ikan pindang dan ikan asap. Disamping itu pengaruh kepemilikan perahu dan alat tangkap merupakan kesejangan bagi para wanita di lokasi penelitian, dimana istri nelayan tidak dapat berbuat banyak dalam pengelolaannya, sehingga keputusannya penuh berada di tangan suami, untuk aktivitas mendidik anak sekolah pengambilan keputusan dilakukan bersama sama.

\section{Tabel 7. Sebaran Pengambilan Keputusan dalam Kegiatan Publik di Kota Semarang Utara.}

Table 7. The Distribution of Decision-Making in Public Activities in the City of North Semarang.

\begin{tabular}{|c|c|c|c|c|}
\hline \multirow[b]{2}{*}{ No } & \multirow[b]{2}{*}{ Aktifitas Produktif/ Productive Activity } & \multicolumn{3}{|c|}{$\mathrm{N}=\mathbf{3 0}$ (orang) } \\
\hline & & $\begin{array}{l}\text { Dominasi } \\
\text { Istri/ Wife } \\
\text { Domination }\end{array}$ & $\begin{array}{c}\text { Suami + Istri/ } \\
\text { Husband + } \\
\text { Wife }\end{array}$ & $\begin{array}{l}\text { Dominasi } \\
\text { Suami/ } \\
\text { Domination } \\
\text { Husband }\end{array}$ \\
\hline \multirow[t]{4}{*}{1} & Investasi/modal usaha perikanan/Investment & & & \\
\hline & - Penetapan besar modal/ Determination of capital & 0 & $26(83.34)$ & $4(16.66)$ \\
\hline & $\begin{array}{l}\text { - Menambah/mengurangi modal/Increase/Decrease } \\
\text { in capital }\end{array}$ & 0 & $27(90)$ & $3(10)$ \\
\hline & - Meminjam modal/ Capital borrowing & 0 & $26(83.34)$ & $4(16.66)$ \\
\hline \multirow[t]{7}{*}{2} & Pengelolaan usaha perikanan/ Fisheries management & & & \\
\hline & - Memilih jenis alat tangkap/ Select type of fishing gear & 0 & $7(24.13)$ & $22(75.87)$ \\
\hline & $\begin{array}{l}\text { - Perbaikan/ganti alat tangkap/ Repair/Replace gear } \\
\text { capture timing }\end{array}$ & 0 & $8(26.67)$ & $22(73.33))$ \\
\hline & - Penetapan Waktu Penangkapan/ & 0 & $7(24.13)$ & $22(73.33)$ \\
\hline & - Penetapan Harga/ Pricing & $4(13.79)$ & $11(37.93)$ & $14(48.27)$ \\
\hline & $\begin{array}{l}\text { - Pemilihan sistem pemasaran/ Selection of marketing } \\
\text { systems }\end{array}$ & $5(17.24)$ & $13(44.82)$ & $11(37.93)$ \\
\hline & $\begin{array}{l}\text { - Pemilihan sistem pembayaran/Selection of payment } \\
\text { system }\end{array}$ & $5(17.24)$ & $14(48.27)$ & $10(34.48)$ \\
\hline \multirow[t]{4}{*}{3} & $\begin{array}{l}\text { Pengelolaan usaha pengolahan/ Business management } \\
\text { processing }\end{array}$ & & & \\
\hline & - Memilih jenis pengolahan/ Select type of processing & $8(50.00)$ & $6(37.5)$ & $2(12.5)$ \\
\hline & - Menentukan skala usaha/ Define the business scale & $6(40.00)$ & $9(60.00)$ & 0 \\
\hline & $\begin{array}{l}\text { - Memilih sistem pemasaran hasil olahan/ Select } \\
\text { System Marketing of Processed }\end{array}$ & $9(50.00)$ & $6(40.00)$ & 0 \\
\hline
\end{tabular}




\section{Lanjutan Tabel 7/Continue Table 7}

\begin{tabular}{|c|c|c|c|c|}
\hline \multirow[b]{2}{*}{ No } & \multirow[b]{2}{*}{ Aktifitas Produktif/ Productive Activity } & \multicolumn{3}{|c|}{$\mathrm{N}=\mathbf{3 0}$ (orang) } \\
\hline & & $\begin{array}{l}\text { Dominasi } \\
\text { Istri/ Wife } \\
\text { Domination }\end{array}$ & $\begin{array}{c}\text { Suami + Istri/ } \\
\text { Husband + } \\
\text { Wife }\end{array}$ & $\begin{array}{l}\text { Dominasi } \\
\text { Suami/ } \\
\text { Domination } \\
\text { Husband }\end{array}$ \\
\hline \multirow[t]{4}{*}{4} & $\begin{array}{l}\text { Pengelolaan usaha pengolahan }(n=25) / \text { Processing of } \\
\text { business management }\end{array}$ & & & \\
\hline & - Pemilihan jenis usaha/ Selection of business & $2(8.33)$ & $14(58.33)$ & $8(34)$ \\
\hline & - Penetapan skala usaha/Determination scale & $2(8.34)$ & $11(45.83)$ & $11(45.83)$ \\
\hline & - Pelaksanaan usaha/ Conducting business & $1(4.16)$ & $16(66.66)$ & $7(29.17)$ \\
\hline \multirow[t]{5}{*}{5} & Sosial kemasyarakatan/ Social community $(n=29)$ & & & \\
\hline & $\begin{array}{l}\text { - Kegiatan pengajian/keagamaan/ Activities pengajian/ } \\
\text { religious }\end{array}$ & $3(9.94)$ & $27(84.38)$ & $2(6.25)$ \\
\hline & - Kegiatan posyandu /PKK/ Activities of Posyandu/PKK & $26(86.67)$ & $3(10.00)$ & $1(3.33)$ \\
\hline & - Kegiatan gotong royong/ Activity mutual cooperation & $1(3.33)$ & $28(94.34)$ & $1(3.33)$ \\
\hline & - Kegiatan perayaan/ Celebration activities & 0 & $27(89.33)$ & $3(11.67)$ \\
\hline
\end{tabular}

Sumber : Data primer, diolah 2007/Source: Primary data processed, 2007

\section{KESIMPULAN DAN IMPLIKASI KEBIJAKAN}

\section{Kesimpulan}

Hasil riset menunjukkan bahwa pekerjaan utamanya responden adalah sebagai juragan darat dan juragan laut atau anak buah kapal (ABK). Istri nelayan $46,67 \%$ mempunyai pekerjaan sebagai pengolah ikan, $14,67 \%$ sebagai pedagang ikan olahan dan $13,36 \%$, sebagai bakul ikan. Status sosial nelayan adalah $94,34 \%$ adalah anggota masyarakat biasa, 3,33\% merupakan tokoh masyarakat dan tokoh agama, sedangkan istri nelayan adalah $100 \%$ merupakan anggota masyarakat biasa.

Curahan waktu kegiatan produktif masih didominasi oleh suami 9,42 jam/hari dan istri adalah 2,60 jam/hari, sedangkan kegiatan domestik didominasi oleh istri nelayan yaitu 8,50 jan/hari dan curahan waktu suami adalah 3,98 jam/hari. Aktivitas sosial suami dan istri adalah 5,40 dan 2,90 jam/ minggu. Dalam pengambilan keputusan pada kegiatan domestik pengambilan keputusan pada umumnya dilakukan secara bersama sama antara suami istri.
Pengambilan keputusan dalam kegiatan produktif seperti investasi $83,34 \%$ suami istri, pengelolaan usaha perikanan $90 \%$ didominasi oleh suami, sedangkan sosial kemasyarakatan $84,38 \%$ pengambilan keputusan dilakukan secara bersamasama. Sedangkan pengambilan keputusan domestik peranan istri lebih besar bila dibandingkan dengan suami dimana dalam mempersiapkam makanan masih didominasi oleh istri,sedangkan untuk menabung, pengadaan alat rumah tangga pengambilan keputusan dilakukan secara bersama sama antara suami istri. Dan pengambilan keputusan untuk aktivitas kesehatan suami menyerahkansepenuhnya kepada istri.

\section{Implikasi Kebijakan}

Dalam pemberdayaan masyarakat nelayan khususnya wanita nelayan dapat dipertimbangkan dalam meningkatkan pendapatan keluarga di Kota Semarang Utara:

1. Perlu adanya program yang responsif terhadap peran gender karena wanita nelayan di Kota Semarang Utara sudah 
banyak terlibat aktif dalam usaha perikanan tangkap dan harus diberikan kesempatan kepada wanita nelayan untuk membentuk kelompok nelayan pengolah.

2. Perlu adanya program - program pembangunan kedepan yang memperhatikan dan menyediakan kesempatan kepada kaum wanita dalam mengembangkan kemampuan dirinya sehingga setara dengan laki laki.

3. Mempemudah akses permodalan bagi wanita nelayan untuk mengembangkan usaha dibidang perikanan seperti pengolahan dan perlu adanya peran pendamping dari instansi terkait.

\section{DAFTAR PUSTAKA}

CIDA, Agritem dan LP3ES. 1999. Assesment Jaringan Kerja Kelembagaan Untuk Gender Mainstreaming, Lembaga Penelitian Pendidikan dan Penerangan Ekonomi dan Sosial.

Djuarsa, S. dan R. Turnomo. 1994. Teori Komunikasi, Jakarta

Fakih, M. 2003. Analisis Gender dan Transformasi Sosial. Pustaka Pelajar. Yogyakarta.

Kusnadi. 2001. Pengamba : Kaum Perempuan Fenomena : Humaniora Utama Press Bandung. 237 hal
Laporan Penelitian Bank Dunia, 2002. Pembangunan Berperspektif Gender, Engendering Development Melalui Perspektif Gender Dalam Hak, Sumberdaya, dan Asprirasi. Laporan Penelitian Bank Dunia, Dian Rakyat. Jakarta.

Mulyana, D. 1996. Prinsip-prinsip Dasar. P.T. Remaja Rodakarya Bandung.

Rahardjo, D. 1995. Program-Program Aksi untuk Mengatasi Kemiskinan dan Kesejahteraan Pada PJP II Dalam awan Setya Dewanta dkk (editor). Kemiskinan dan Kesenjangan di Indonesia. Yogyakarta: Aditya Media.

Sitorus, 1998. Penelitian Kualitatif. Suatu Pendekatan. Labotariun Sosiologi, Antropologi dan Kependudukan. Jurusan Ilmu-IImu Sosial dan Ekonomi Pertanian. Fakultas Pertanian Institut Pertanian Bogor.

Srini, S., V. Malisa, M. Kombon, A. Tegeke dan T. Kogoyo. 2000. Gender in Development Jayawijaya Watch Project. Irian Jaya.

Soekanto, S. 1990. Sosiologi Suatu Pengantar. PT Raja Grafindo Persada. Jakarta

Seruan, 2000. Study Gender Pada Rumah tangga Nelayan Dalam Pengelolaan Sumberdaya Pesisir dan Lautan, Bogor. Tesis Program Pascasarjana. IPB. Bogor

Yin, K.K. 2002. Study Kasus: Desain dan Metoda. Raja Grafindo Persada. Jakarta 